\title{
Project Based Learning (Pjbl) dalam Proses Pembelajaran Daring pada Materi Hukum Bernoulli Menggunakan Botol Bekas
}

\author{
Sutejo $^{1}$, Lakon Wahono ${ }^{1}$, Eka Yuli Sari Asmawati ${ }^{1}$, Nyoto Suseno ${ }^{2 *}$ \\ ${ }^{1}$ Guru Mata Pelajaran Fisika, SMA Negeri 1 Metro \\ ${ }^{2}$ Program Studi Pendidikan Fisika, Universitas Muhammadiyah Metro \\ *Email: nyotoseno@gmail.com
}

Received: 25 November 2021; Accepted: 30 Desember 2021; Published: 30 Desember 2021 DOI: http://dx.doi.org/10.29303/jpft.v7i2.3268

\begin{abstract}
Covid-19 has an impact on education. In order to maintain the quality of learning, online mode learning innovation is carried out with the application of project based learning through experiments in the application of Bernoulli's Law on used bottle leaks. Online learning at SMAN 1 Metro usually uses Problem Based Learning. In this study will be used PjBl to increase the creativity of students. This research aims to explore students' ability in problem solving in dynamic fluid concepts. This type of research is quantitative with a Quasi Experimental approach, and the design used is Nonequivalent Group Design. The subject of the study was Sma N 1 Metro in class XI IPA which numbered 67 students. The analysis method uses the N-Gain Test and the different tests between the two sample groups. Results: $N$-Gain in experimental class by $65.74 \%$ and in control class by $25.04 \%$. Based on hypothesis tests, it was found that the effect of applying madel project based learning in improving student learning outcomes in Bernoulli Law material. Project based learning model in online learning is also effective in developing 4 Cs.
\end{abstract}

Keywords: Bernoulli's Law; Online Learning; Project Based Learning

\section{PENDAHULUAN}

Wabah Covid-19 telah melanda lebih dari 200 negara di dunia. Hal ini membuat pemerintah mengeluarkan kebijakan untuk mengantisipasi penularan virus, seperti isolasi, social and physical distancing hingga pembatasan sosial berskala besar (PSBB) (Siregar et al., 2020). Untuk mempertahankan mutu pendidikan, maka pemerintah memberlakukan program daring untuk berlangsungnya pembelajaran di sekolah maupun perguruan tinggi (Syarifudin, 2020). Pembelajaran daring dipadu dengan praktikum dapat digunakan dalam situasi pandemi covid-19 (Suseno et al., 2021). Menurut (Jayul \& Irwanto, 2020) Pembelajaran daring menjadi pilihan terbaik untuk mencegah penularan virus covid-19.

$$
\text { Pembelajaran daring menjadi }
$$

kelaziman baru (Suseno et al., 2021). Banyak fasilitas daring tersedia secara open akses. Revolusi Industri 4.0 menyediakan sistem komunikasi dan penyimpanan data yang praktis dengan sistem Cyber (Suseno et al., 2019). Modul fisika online dapat digunakan sebagai sumber belajar mandiri. (Sari et al., 2019). Pembelajaran daring dapat menggunakan google meet yang mudah dan tidak perlu didownload (Haryani, 2020). Google meet sebagai solusi pembelajaran langsung melalui video konferensi (Wijyanto et al., 2021). Fasilitas daring lainya adalah google classroom yang dirancang untuk memudahkan interaksi antara dosen dan mahasiswa dalam dunia maya (Sutrisna, 2018), sebagai media dalam penugasan paperless (Gunawan \& Sunarman, 2018). Serta dengan google classroom guru dapat mengelola pembelajaran dan menyampaikan informasi secara tepat dan akurat kepada peserta didik (Hakim, 2016) dan banyak fasitas daring yang dapat digunakan.

Proses pendidikan mengarahkan siswa untuk menerima informasi yang 
digunakan untuk berpikir sehari-hari berdasarkan ilmu yang diperoleh, salah satunya mata pelajaran Fisika. Pada dasarnya Fisika mengajarkan siswa untuk berfikir secara ilmiah dan beraktivitas secara kolaboratif sesuai tantangan pendidikan abad 21, salah satunya melalui praktikum. Praktikum dapat mengembangkan hasil belajar berupa sikap, psikomotor dan kognitif (Suseno, 2012). Ciri abad 21 adalah multitasking, multimedia, online social networking, online inform searching, gameonline (Kurniawan, 2019). Hal ini membawa konten abad 21 mencakup keterampilan belajar dan berpikir, literasi TIK dan keterampilan hidup (Winaryati, 2018). Pembelajaran yang terintegrasi dengan media sosial penting mendapat perhatian seiring perkembangannya (Kartikawati \& Pratama, 2017).

Aktivitas belajar siswa lebih meningkat ketika guru menerapkan eksperimen (Furqon \& Kholida, 2020). Model pembelajaran tersebut dapat memberikan pengalaman langsung kepada siswa (Suseno, dkk., 2019). Metode praktikum dapat mengembangkan hasil belajar berupa sikap, psikomotor dan kognitif (Suseno, 2012). Pengaruh model pembelajaran perpaduan sistem daring dan praktikum signifikan dan efektif dalam meningkatkan kemampuan kognitif, maupun psikomotor (Suseno, dkk., 2021). Suasana yang menyenangkan juga harus dimunculkan ketika melakukan eksperimen (Suarja \& Aswadi, 2016), sehingga siswa dapat lebih memahami dan mengaplikasikannya dalam kehidupan sehari-hari maupun pada teknologi yang berkembang saat ini.

Berdasarkan observasi pembelajaran daring saat ini, siswa kurang mampu untuk fokus dalam pembelajaran. Seperti halnya, tugas-tugas yang diberikan bisa saja hanya menyalin atau saat pembelajaran berlangsung, siswa tidak terfokus pada materi dikarenakan sinyal ataupun hal eksternal lainnya. Untuk mengatasi hal tersebut, maka digunakan model pembelajaran yang digunakan adalah Project Based Learning (PjBL). PjBL merupakan salah satu pembelajaran aktif yang melibatkan siswa secara mandiri dapat berfikir kognitif terhadap proyek yang dikerjakan melalui permasalahan yang ditemukan. PjBL juga memberi peluang untuk memahami konten dan penerapannya (Larmer et al., 2015). Kegiatan eksperimen dilakukan secara kolaboratif untuk meningkatkan motivasi belajar siswa (Suseso, 2019).

Oleh sebab itu, agar penguasaan konsep fisika pada siswa tercapai dan untuk meningkatkan keantusiasan siswa, dilakukanlah eksperimen penerapan Hukum Bernoulli pada kebocoran botol bekas untuk meningkatkan kreativitas siswa dalam proses pembelajaran daring. Tujuan dari penelitian ini adalah mengeksplorasi kemampuan siswa dalam pemecahan masalah fluida dinamis.

\section{METODE PENELITIAN}

Penelitian menggunakan pendekatan quasi experimental. Desain yang digunakan yaitu Nonequivalent Group Design. Subjek penelitian ini adalah SMA N 1 Metro. Pembelajaran dilaksanakan secara daring dan biasanya menggunakan Problem Based Learning (PBL). Populasi penelitian ini yaitu dua kelas dengan total 67 siswa, yang terdiri dari kelas XI IPA 3 (33 siswa) sebagai eksperimen dan XI IPA 4 (34 siswa) sebagai kontrol. Desain penelitian dapat dilihat pada Tabel 1.

Tabel 1. Desain Penelitian

\begin{tabular}{lllll}
\hline Kelompok & $\begin{array}{l}\text { Pre } \\
\text { test }\end{array}$ & Perlakuan & $\begin{array}{l}\text { Post } \\
\text { test }\end{array}$ \\
\hline Eksperimen & $\mathrm{O}_{1}$ & $\longrightarrow$ & $\mathrm{X}_{1}$ & $\mathrm{O}_{2}$ \\
Kontrol & $\mathrm{O}_{3}$ & $\longrightarrow$ & $\mathrm{X}_{2}$ & $\mathrm{O}_{4}$ \\
\hline
\end{tabular}


Keterangan:

$\mathrm{O}_{1}$ : Kemampuan kelompok eksperimen sebelum diberikan perlakuan

$\mathrm{O}_{2}$ : Kemampuan kelompok eksperimen setelah diberikan perlakuan

$\mathrm{X}_{1}$ : Perlakuan dengan model pembelajaran Project Based Learning

$\mathrm{X}_{2}$ : Perlakuan dengan model pembelajaran Problem Based Learning

$\mathrm{O}_{3}$ : Kemampuan kelompok kontrol sebelum diberikan perlakuan

$\mathrm{O}_{4}$ : Kemampuan kelompok kontrol setelah diberikan perlakuan

Pada penelitian ini kelompok eksperimen (XI IPA 3) sebagai $\mathrm{X}_{1}$ dilakukan pembelajaran PBL disertai dengan model Project Based Learning. Sedangkan pada kelompok kontrol (XI IPA 4) sebagai $\mathrm{X}_{2}$ dilakukan pembelajaran dengan model Problem Based Learning sebagaimana biasanya. Data yang dikumpulkan dalam penelitian ini merupakan penguasaan konsep dengan teknik pengumpulan data tes dan non-tes. Pada awal pembelajaran, masingmasing kelas dilakukan tes permulaan berupa pre-test dengan tujuan untuk mengukur kemampuan awal. Selanjutnya pada kelas eksperimen dilakukan pembelajaran dengan project based learning dan kelas kontrol menggunakan problem based learning. Tahap terakhir adalah melakukan post-test, bertujuan untuk mengetahui seberapa besar perubahan yang dialami siswa dalam peningkatan ketercapaian penguasaan konsep setelah diberikan treatment.

Efektivitas model pembelajaran project based learning dan problem based learning dapat dilihat dari total pre test dan post test pada kelompok eksperimen dan kelompok kontrol. Instrumen tes untuk mengukur tingkat pemahaman siswa terdiri dari 10 butir pertanyaan. Teknik analisis data meliputi analisis uji prasyarat dan uji hipotesis. Uji prasyarat merupakan uji yang harus dilakukan dalam memilih teknik pengujian yang tepat pada pembuktian hipotesis penelitian. Uji prasyarat meliputi uji normalitas data dan uji homogenitas varians. Data yang digunakan untuk uji hipotesis diperoleh dengan menghitung $\mathrm{N}$ Gain Score dengan menggunakan rumus :

$$
N-\text { gain }=\frac{S_{\text {post }}-S_{\text {pre }}}{S_{\text {max }}-S_{\text {pre }}}
$$

Keterangan :

$S_{\text {post }} \quad$ : Nilai post tes

$S_{\text {pre }} \quad$ : Nilai pre tes

$\mathrm{S}_{\max } \quad$ : Nilai max

Kategori atau tafsiran dari nilai $\mathrm{N}$ Gain Score dapat menggunakan nilai N Gain langsung atau dalam bentuk presentase.

Tabel 2. Pembagian skor gain (N Gain Langsung)

\begin{tabular}{cc}
\hline Nilai N-gain & Kategori \\
\hline $\mathbf{g}>\mathbf{0 , 7}$ & Tinggi \\
$\mathbf{0 , 3} \geq \mathbf{g} \geq \mathbf{0 , 7}$ & Sedang \\
$\mathbf{g}<\mathbf{0 , 3}$ & Rendah \\
\hline
\end{tabular}

Tabel 3. Kategori Efektivitas N Gain

\begin{tabular}{cc}
\hline Presentase (\%) & Tafsiran \\
\hline$>\mathbf{7 6}$ & Efektif \\
$\mathbf{5 6 - 7 5}$ & Cukup Efektif \\
$\mathbf{4 0 - 5 5}$ & Kurang Efektif \\
$<\mathbf{4 0}$ & Tidak Efektif \\
\hline
\end{tabular}

\section{HASIL DAN PEMBAHASAN}

Data penelitian ini berupa data pretest dan post tes yang telah dilakukan pada kelas eksperimen dan kelas kontrol. Hasil pre-test dan post-test pada kelas eksperimen dan kelas kontrol disajikan pada Tabel 4.

Selain data kuantitatif, dari hasil observasi pada penerapan PjBL mode daring ini juga ditemukan beberapa aktivitas siswa yang mengarah pada pengembangan critical thinking and problem solving, collaboration, creative thinking, and communication (4Cs). 
Tabel 4. Data pre tes dan pos tes

\begin{tabular}{|c|c|c|c|c|c|}
\hline \multirow[t]{2}{*}{ No } & \multirow[t]{2}{*}{ Parameter } & \multicolumn{2}{|c|}{$\begin{array}{l}\text { Kelas } \\
\text { Eksperimen }\end{array}$} & \multicolumn{2}{|c|}{$\begin{array}{l}\text { Kelas } \\
\text { Kontrol }\end{array}$} \\
\hline & & $\begin{array}{l}\text { Pre } \\
\text { tes }\end{array}$ & $\begin{array}{l}\text { Post } \\
\text { tes }\end{array}$ & $\begin{array}{l}\text { Pre } \\
\text { tes }\end{array}$ & $\begin{array}{l}\text { Post } \\
\text { tes }\end{array}$ \\
\hline 1 & $\begin{array}{l}\text { Jumlah } \\
\text { siswa }\end{array}$ & 33 & 33 & 34 & 34 \\
\hline 2 & Rata-rata & 79,5 & 94,3 & 77,5 & 80,3 \\
\hline 3 & $\begin{array}{l}\text { Nilai } \\
\text { Tertinggi }\end{array}$ & 85 & 95 & 80 & 85 \\
\hline 4 & $\begin{array}{l}\text { Nilai } \\
\text { Terendah }\end{array}$ & 76 & 83 & 75 & 75 \\
\hline
\end{tabular}

Berpikir kritis dan problem solving ditunjukkan dengan aktivitas bertanya, menjawab pertanyaan dan juga menyelesaiakan tugas proyeknya. Kolaborasi ditunjukkkan dengan aktivitas bekerjasama dalam kelompok dalam mengerjakan proyek. Kreativitas diperlihatkan dari jawaban siswa ketika berdiskusi dan produk yang dibuat, berupa video percobaan, laporan dan bahan presentasi yang dihasilkan. Sedangkan keterampilan komunikasi diperlihatkan pada kegiatan pemaparan hasil dan diskusi pada saat pembelajaran berbasis proyek dilaksanakan.

\section{Hasil}

Berdasarkan data hasil pre-test dan post-test, dapat dihitung nilai $\mathrm{N}$ Gain baik pada kelas eksperimen maupun kelas kontrol. Data perhitungan N-Gain disajikan pada Tabel 5.

Tabel 5. Rata-rata N Gain

\begin{tabular}{llll}
\hline No & $\begin{array}{l}\text { Perolehan } \\
\text { Skor }\end{array}$ & $\begin{array}{l}\text { Kelas } \\
\text { Eksperimen }\end{array}$ & $\begin{array}{l}\text { Kelas } \\
\text { Kontrol }\end{array}$ \\
\hline $\mathbf{1}$ & N Gain Max & 78,26 & 37,50 \\
$\mathbf{2}$ & N Gain Min & 31,82 & 9,09 \\
$\mathbf{3}$ & Rata-rata & 65,74 & 25,04 \\
$\mathbf{4}$ & Kategori & Cukup & Tidak \\
& & Efektif & Efektif \\
\hline
\end{tabular}

Berdasarkan data pada Tabel 5, pengujian terhadap kelas eksperimen dengan model project-based learning menunjukkan kategori cukup efektif dibandingkan dengan kelas kontrol dengan model problem based learning.

Selanjutnya dilakukan uji hipotesis statistik untuk melihat perbedaan antara skor pre-test maupun post-test, baik pada data kelas eksperimen maupun kelas kontrol. Hasil uji perbedaan nilai pre-test antara kelas eksperimen dan kelas kontrol, diperoleh nilai Signifikansi sebesar 0,27, lebih besar dari 0,05. Dengan demikian untuk perbedaan nilai pre-test terima Ho, yang berarti tidak ada perbedaan nilai awal antara kelas eksperimen dan kelas kontrol.

Sedangkan untuk nilai post-test antara kelas eksperimen dengan kelas kontrol diperoleh nilai Signifikansi sebesar 0,01, lebih kecil dari 0,05. Dengan demikian $\mathrm{H}_{\mathrm{o}}$ ditolak, yang berarti ada perbedaan hasil belajar (post-test) antara kelas eksperimen dengan kelas kontrol. Dengan demikian, maka dapat disimpulkan bahwa terdapat pengaruh yang signifikan antara model project based learning menggunakan botol bekas terhadap peningkatan penguasaan konsep siswa pada materi Hukum Bernoulli.

\section{Pembahasan}

Hasil penelitian ini adalah adanya pengaruh yang signifikan antara penerapan model PjBL dalam pembelajaran daring terhadap hasil belajar pada materi Hukum Bernoulli. Pada penelitian ini kelas kontrol menggunakan model PBL, karena dalam pembelajaran daring yang dilaksanakan selama pandemi covid-19 di SMA Negeri 1 Metro menggunakan PBL. Analisis yang dilakukan pada penelitian ini adalah membandingkan antara hasil penerapan $\mathrm{PjBL}$ dengan PBL, dan ternyata diperoleh hasil bahwa penerapan PjBL lebih baik dari penerapan PBL pada pembelajaran fisika materi Hukum Bernoulli.

Hasil ini tidak sesuai dengan penelitian (Lestari \& Juanda, 2019) yang menemukan 
bahwa PBL lebih baik dari PjBL pada materi perangkat keras pada jaringan internet. Namun demikian hasil ini sesuai dengan hasil penelitian (Fiana et al., 2019) bahwa pembelajaran $\mathrm{PjBL}$ lebih efektif dalam meningkatkan hasil belajar dibandingkan dengan model PBL.

Efektivitas PjBL juga ditunjukkan dengan aktivitas 4Cs yang juga berjalan baik ketika pembelajaran berbasis proyek dengan mode daring ini dilaksanakan. Semua aktivitas 4C, baik critical thinking and problem solving, collaboration, creative thinking, maupun communication semua berjalan dengan baik. Hal ini sesuai dengan kebutuhan abad 21, bahwa keterampilan 4C sangat diperlukan dalam menghadapi perubahan dan sebagai kompetensi yang dibutuhkan pada abad 21 (Rotherham \& Willingham, 2010; Kurniawan, 2019; Septikasari \& Frasandy, 2018; Suwandi, 2020).

Dengan demikian dapat dikemukakan bahwa penerapan model $\mathrm{PjBL}$ ataupun PBL akan efektif jika menyesuaikan dengan karakteristik materi pembelajaran. Pada penelitian ini Model PjBL lebih sesuai digunakan dalam pembelajaran daring pada materi hukum Bernoulli menggunakan botol bekas.

\section{PENUTUP}

Berdasarkan penelitian yang telah dilakukan, diperoleh kesimpulan bahwa model pembelajaran daring dengan menggunakan project-based learning berpengaruh positif dan signifikan terhadap peningkatan hasil belajar siswa pada materi hukum Bernoulli. Penerapan PjBL dalam pembelajaran daring cukup efektif, karena selain berpengaruh positif terhadap peningkatan hasil belajar, juga memfasilitasi pengembangan $4 \mathrm{Cs}$.

\section{REFERENSI}

Fiana, R. O., Relmasira, S. C., \& Hardini, A. T. A. (2019). Perbedaan Penerapan Model Project Based Learning Dan Problem Based Learning Terhadap Hasil Belajar Matematika Kelas 4 Sd. Jurnal Basicedu, 3(1), 157-162.

Furqon, M., \& Kholida, S. I. (2020). Ketercapaian Konsep Hukum Bernoulli melalui Model Project Based Learning (PjBL) Berbantuan Aeromodelling. Prosiding Seminar Nasional Fisika (SNF), 4, 140-144.

Gunawan, F. I., \& Sunarman, S. G. (2018). Pengembangan kelas virtual dengan google classroom dalam keterampilan pemecahan masalah (problem solving) topik vektor pada siswa SMK untuk mendukung pembelajaran. Prosiding Seminar Nasional Pendidikan Matematika Etnomatnesia.

Hakim, A. B. (2016). Efektifitas penggunaan e-learning Moodle, Google Classroom dan Edmodo. I-Statement, 2 (1), 1-6.

Haryani, E. S. (2020). Efforts to Improve Learning Activeness of Grade 5 Students Through the Google Meet Application. Social, Humanities, and Educational Studies (SHEs): Conference Series, 3(3), 526-530.

Jayul, A., \& Irwanto, E. (2020). Model Pembelajaran Daring Sebagai Alternatif Proses Kegiatan Belajar Pendidikan Jasmani di Tengah Pandemi Covid-19. Jurnal Pendidikan Kesehatan Rekreasi, 6(2), 190-199.

Kartikawati, S., \& Pratama, H. (2017). Pengaruh penggunaan whatsapp messenger sebagai mobile learning terintegrasi metode group investigation terhadap kemampuan berpikir kritis. JUPITER (Jurnal Pendidikan Teknik Elektro), 2(2), 3338.

Kurniawan, S. (2019). Tantangan Abad 21 bagi Madrasah di Indonesia. Intizar, 25(1), 55-68. 
Larmer, J., Mergendoller, J., \& Boss, S. (2015). Setting the standard for project based learning. ASCD.

Lestari, I., \& Juanda, R. (2019). Komparasi Model Pembelajaran Problem Based Learning dan Project Based Learning Terhadap Hasil Belajar Siswa Pada Materi Perangkat Keras Jaringan Internet Kelas IX SMP Negeri 5 Sungai Kakap Kabupaten Kubu Raya. Efektor, 6(2), 127-135.

Rotherham, A. J., \& Willingham, D. T. (2010). 21 st-century" skills. American Educator, 17(1), 17-20.

Sari, F. A., Suseno, N., \& Riswanto, R. (2019). Pengembangan modul fisika online berbasis web pada materi usaha dan energi. JIPFRI (Jurnal Inovasi Pendidikan Fisika Dan Riset Ilmiah), 3(2), 129-135.

Septikasari, R., \& Frasandy, R. N. (2018). Keterampilan 4C abad 21 dalam pembelajaran pendidikan dasar. Tarbiyah Al-Awlad, 8(2), 107-117.

Siregar, H. S., Sugilar, H., Ukit, U., \& Hambali, H. (2020). Merekonstruksi alam dalam kajian sains dan agama: Studi kasus pada masa Pembatasan Sosial Berskala Besar (PSBB) dampak Covid-19. Digital Library UIN Sunan Gunung Djati Bandung.

Suarja, Z. A., \& Aswadi, C. (2016). Penggunaan Laboratorium Virtual Biologi Sebagai Sarana Praktikum yang Efektif dan Efisien untuk Menciptakan Pengalaman Belajar yang Menyenangkan. Jurnal BioNatural, 3(2).

Suseno, N. (2012). Peran praktikum dalam mengembangkan kemampuan dan karakter mahasiswa calon guru fisika pada mata kuliah keahlian program studi (Studi kasus pada perkuliahan elektronika dan listrik magnet). Membangun Karakter Guru Dan Dosen Untuk Mewujudkan Pendidikan Berkarakter. Paper Presented at Seminar Nasional Pendidikan Ke-1,
Universitas Muhammadiyah Metro, Metro, 132-139.

Suseno, N., Harjati, P., \& Dedy, H. A. (2019). School Laboratory Management Information System. Journal of Physics: Conference Series, 1361(1), 12068.

Suseno, N., Riswanto, R., Aththibby, A. R., Alarifin, D. H., \& Salim, M. B. (2021). Model Pembelajaran Perpaduan Sistem Daring dan Praktikum untuk Meningkatkan Kemampuan Kognitif dan Psikomotor. Jurnal Pendidikan Fisika, 9(1), 42-56.

Suseso, N. (2019). Developing Collaborative Habits of Prospective Teachers. The 8th International Conference on Lesson Study (ICLS).

Sutrisna, D. (2018). Meningkatkan Kemampuan Literasi Mahasiswa Menggunakan Google Classroom. FON: Jurnal Pendidikan Bahasa Dan Sastra Indonesia, 13(2).

Suwandi, S. (2020). Implementasi Pembelajaran Abad Ke-21 Dan Tantangannya Untuk Berperan Dalam Masyarakat 5.0. Prosiding Seminar Nasional Program Pascasarjana Universitas PGRI Palembang.

Syarifudin, A. S. (2020). Impelementasi pembelajaran daring untuk meningkatkan mutu pendidikan sebagai dampak diterapkannya social distancing. Jurnal Pendidikan Bahasa Dan Sastra Indonesia Metalingua, 5(1), 31-34.

Wijayanto, A., Or, S., Kom, S., Lani, A. D. A., Ulfa, D. L., Taufik, M. S., \& Akhyak, H. (2021). Penerapan Adaptasi Kebiasaan Baru pada Era Pandemi Virus Corona 19 di Berbagai Sektor Pendidikan. OSF Preprints. January, 24.

Winaryati, E. (2018). Penilaian kompetensi siswa abad 21. Prosiding Seminar Nasional \& Internasional, 1(1). 